\title{
CRIAÇÃO
}

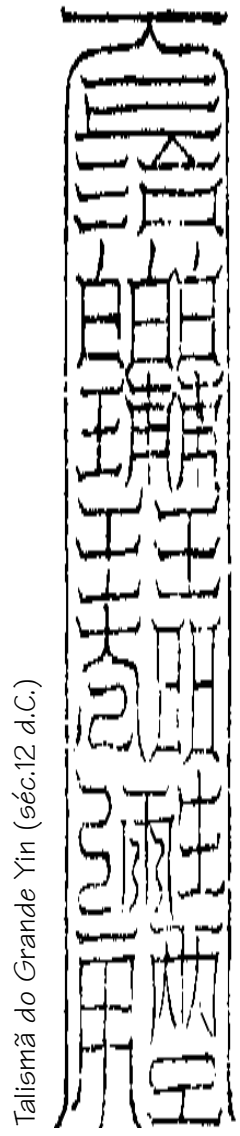

\section{Vivido sobre a areia}

"Toda existência é construída sobre a areia, a morte é a única certeza que temos"

Michel Onfray

- Mas o que a senhora está sentindo?

- Eu sou muito infeliz

O médico diagnosticou um enfisema pulmonar, mas sua dor era brutal. O corpo, um oco desvalido, quase mineral, retraindo-se. Diante do risco de viver, o jeito talvez fosse liqüefazer a carne, distanciar-se para sempre dessa imperiosa força de existir, que teimava. E o corpo ainda insistia em recitar sua desconjuntada sintaxe e se debatia decidido contra aquela prisão incompreensīvel. Afinal, era um corpo abatido, mas ativo, desejando recobrar uma música sutil, quase inaudivel, cheia de chiados e tão exemplarmente sua.

\section{A ressurreição do corpo}

Foi numa sala crua e muito fria. Seu corpo buscava um lugar de desabafo expressivo que pudesse abrigar seus naturais barulhos. Conectada a uma maquinaria inteligente, pronta para registrar os batimentos do coração, sua voz pôde jorrar pura no espaço, ecoando uma canção de órgãos. E a sala vibrou em sons articulados que desenhavam diagramas de vida, passados, presentes, futuros. Naquele instante, a carne se reconciliava com

a existência, esculpindo um tempo outro para aquele corpo violentamente doente, impondo sua singular resistência, inventando toda a saúde que lhe faltava.

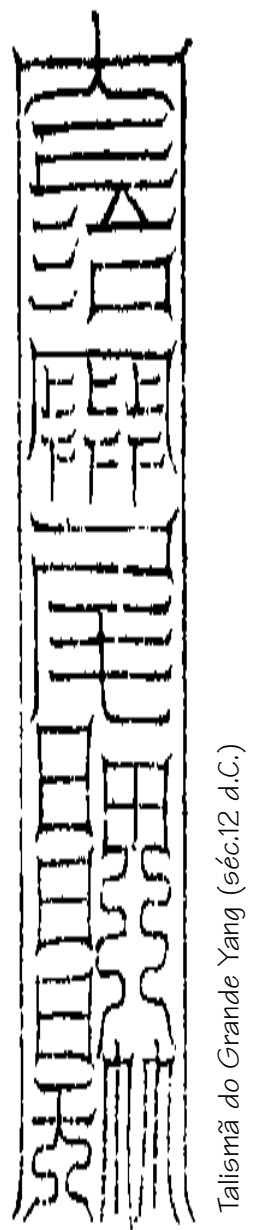


$O$ eixo estendido entre o texto que abre e o texto que fecha este número "quase tecnológico" sugere a mineralização da nossa existência "passageira", de "passageiros" em trânsito para uma morte que não compreendemos mais. Do silício das rochas fazemos os microprocessadores que integram os circuitos da nossa contemporânea existência; dos grãos de rocha (areia) é feita nossa existência. Com gipsita molhada (gesso) petrificamos "passageiros" humanos, para sempre paralisados numa viagem insólita: cálcio calcinado congelando o trânsito e as trocas possíveis através dessa impressionante pele de osso. 